\title{
TRAGEDIA „WYZWOLENIA” CHIN KONTYNENTALNYCH W NOWEJ KSIĄŻCE FRANKA DIKÖTTERA
}

\author{
Jakub Polit
}

Uniwersytet Jagielloński w Krakowie

\author{
ABSTRACT \\ THE TRAGEDY OF CONTINENTAL CHINA “LIBERATION" IN FRANK \\ DIKÖTTER'S LATEST BOOK
}

Frank Dikötter shows the formative years of the Chinese Communist regime, a period often seen as relatively peaceful compared with what followed. Drawing on newly-opened provincial archives, as well as quoting old and well-known but forgotten non-Communist Chinese and Western sources, he convincingly debunks the myth of the "golden" years of Mao's dictatorship. Focusing on neither internal party intrigues nor foreign policy, but on everyday experiences of ordinary people, this revisionist book reconstructs the regime of tyranny, which brought on widespread misery rather than a time of "liberation."

Key words: People's Republic of China, Chinese Revolution, formative years, Communist terror.

Słowa kluczowe: Chińska Republika Ludowa, rewolucja chińska, pierwsze lata, komunistyczny terror.

Od pojawienia się w 2014 roku anglojęzycznego oryginału The Tragedy of Liberation Franka Diköttera niecierpliwie oczekiwałem polskiego przekładu tej książki ${ }^{1}$; nadzieję dawało tłumaczenie Wielkiego Głodu tegoż autora, dokonane przez Wydawnictwo Czarne. Tragedia wyzwolenia jest zapewne najlepiej napisaną, jeśli nie po prostu najlepszą, syntezą wczesnego okresu rządów komunistów w Chinach. Jej lektura nasuwa wszakże rozmaite pozanaukowe refleksje.

1 F. Dikötter, Tragedia wyzwolenia. Historia rewolucji chińskiej 1945-1957, tłum. B. Gadom ska, Wołowiec 2016, ss. 407. 
Autorowi należą się słowa pochwały za sam wybór tematu książki i jej błyskotliwe (acz w pełni usprawiedliwione) zatytułowanie. Nawet bowiem w opinii krytyków Mao pierwsze lata ChRL uchodzą powszechnie za ,złote lata Chin Ludowych, nacechowane bezgranicznymi nadziejami i szczerym optymizmem"'2. Chen Yun, czołowy (obok Deng Xiaopinga) partyjny architekt reform rynkowych w Chinach, potępiający dokonane przez wodza wypaczenia, głosił wszak, że „gdyby Mao zmarł w 1956 r., jego osiągnięcia byłyby nieśmiertelne" . Polecana obecnie obcokrajowcom przez władze ChRL anglojęzyczna synteza Chińska droga zapewnia, iż w owym heroicznym okresie „Chiny przesiąknięte były atmosferą idealizmu. Duma narodowa spowodowana udaną rewolucją i odzyskaniem suwerenności była wyraźnie widoczna”. Ludzie „dokonali wielkich postępów”, a „problemy pojawiły się głównie z powodu historycznych ograniczeń i były trudne do uniknięcia w procesie rozwoju"4.

Dikötter bezkompromisowo uderza w ów mit założycielski chińskiego komunizmu. Udowadnia, że nie chodziło o trafną, lecz potem wypaczoną ideę, ale że (używając chińskiego sformułowania) „robak lągł się w kwiecie” od samego początku. Publicystycznie sformułowany tytuł kwestionuje może najbardziej pieszczoną przez maoistów legendę „,wyzwolenia”, jak do dziś w ChRL określa się zwycięstwo komunistów w 1949 roku. Od kogo bowiem ludność Chin wyzwolono, skoro zależność od obcego mocarstwa była po roku 1949 wyraźnie większa niż po tej dacie, w większości zaś dziedzin życia nastąpiło pogorszenie?

Podkreślić trzeba, że autor miał wyjątkowe kompetencje do napisania takiej książki. Jako dobrze znający język chiński profesor uniwersytetu w Hongkongu spenetrował nie tylko Archiwum Narodowe (Guoshiguan) Republiki Chińskiej (na Tajwanie), ale także, acz wybiórczo, zbiory MSZ w Pekinie i prowincjonalne archiwa w ChRL; wyliczenie odpowiednich zespołów zajmuje dwie i pół strony. Podkreślić należy, iż w Chinach Ludowych w miarę swobodny dostęp do źródeł dotyczy właśnie archiwów lokalnych; o kłopotach w tej dziedzinie w skali ogólnopaństwowej autor napomyka na stronie 321. Oprócz tego wykorzystane zostały archiwalia amerykańskie, brytyjskie, szwajcarskie zespoły Międzynarodowego Czerwonego Krzyża, wreszcie - co należy szczególnie podkreślić - kolekcje RGSPI w Moskwie (Dikötter jest absolwentem rusycystyki). Do tego dochodzi obszerna literatura przedmiotu nie tylko w językach chińskim i angielskim. Jest to niezwykłe, bowiem - odwołać się tu mogę do własnej praktyki badawczej - władający chińszczyzną autorzy anglosascy zwykle ograniczają się poza nią do kręgu ojczystej mowy. Nawet język Moliera (nie mówiąc już o Puszkinie) stanowi dla nich barierę zwykle niemożliwą do przekroczenia.

Praca nie jest $\mathrm{w}$ najmniejszej nawet mierze podręcznikiem, ale raczej szeroką panoramą państwa i społeczeństwa kontynentalnych Chin w latach 1945-1957. Pod

2 W. Rodziński, Historia Chin, Wrocław 1992, s. 695. Opinię tę ów autor (pisujący głównie po angielsku) spopularyzował szeroko w pracy The People's Republic of China: Reflections on Chinese Political History since 1949, London 1988.

3 China: Big Bad Wolf, „The Economist”, 31 VIII 2006, http://www.economist.com/node/7854042 [dostęp: 12.11.2016]; zob. też: D. Davin, Mao Zedong, thum. E. Spirydowicz, Warszawa 2000, s. 91.

${ }^{4}$ H. Li, Y. Gong, Q. Song, Chińska droga, thum. K. Kukow ska, Toruń 2014, s. 98 i 97 (oryginalne wydanie 2014; zob. moją recenzję tej pracy w: „Studia Historyczne” 2015, nr 1, s. 136-138). 
tym względem przypomina najlepsze narracyjnie dzieła historyków piszących po angielsku, choćby popularnego w Polsce Timothy'ego Syndera. Ma układ chronologiczno-problemowy. W czterech częściach, pod znamiennymi tytułami: Podbój, Przejęcie władzy, Umacnianie rė̇ymu, Reakcja, znajdują się rozdziały opisujące rozmaite aspekty chińskiej rzeczywistości. Podkreślić trzeba, że z uwagi na charakter wykorzystanych źródeł (archiwa lokalne) przeważa tu spojrzenie z perspektywy oddolnej. Dotyczy to nawet takich wydarzeń, jak wojna domowa, udział Chin w wojnie koreańskiej, przepędzenie niemal wszystkich mieszkających w Państwie Środka cudzoziemców (rozdz. Bambusowa kurtyna). Rozwiązanie to powitać należy $\mathrm{z}$ aprobatą, bo o decyzjach podjętych na partyjno-państwowych szczytach napisano już (zwłaszcza na Zachodzie) bez porównania więcej.

Innymi słowy, Dikötter przyjął w swej pracy perspektywę przeciętnego mieszkańca Chin Ludowych, to znaczy (przynajmniej do 1949 r.) bezpartyjnego. Dotychczas historycy zachodni koncentrowali się na analizowaniu wyborów i rozterek Mao, Zhou Enlaia, Deng Xiaopinga. Funkcjonariusze partyjni ze stażem sprzed „wyzwolenia" stanowili tymczasem wyobcowaną ze społeczeństwa mniejszość, a ich doświadczenia, skądinąd burzliwe oraz ciekawe, określić trzeba jako absolutnie niereprezentatywne. Owszem: autor Tragedii wyzwolenia poświęcił nieco uwag partyjnym wodzom, podważając mit o niezależności Mao Zedonga od Moskwy i mocno nadwyrężając hołubiony zwykle w historiografii, posągowy wizerunek Zhou Enlaia (por. rozdz. 11; potwierdza on w pełni werdykt byłego oficjalnego biografa premiera, iż „Zhou starał się być porządnym człowiekiem, ale mu się nie udało"5). Nie rządzący wszakże (będący czasem po prostu oprawcami) są głównymi bohaterami książki, ale ich ofiary.

W Tragedii wyzwolenia Frank Dikötter kontynuuje tezę postawioną przez siebie już wcześniej, że komunistyczny „nowy wspaniały świat” zniszczył świat stary, znacznie od niego lepszy. Holenderski badacz (piszący po angielsku Dikötter urodził się w Stein w Limburgii) w rzeczy samej otwarcie rehabilituje zniszczoną na kontynencie przez KPCh Republikę Chińską. W swej ważnej pracy The Age of Openess: China Before Mao (Hong Kong 2008) argumentował, zdaniem jednego z recenzentów, że przedmaoistowskie Chiny były, ,przynajmniej przez pewien czas, bardziej demokratyczne niż wiele porównywalnych krajów w Europie (i prawie wszystkie w Azji), mniej zmilitaryzowane per capita niż można by przypuszczać, ze znaczną stabilnością i stałością w skali lokalnej (nawet jeśli rząd centralny był słaby) i z liczącymi się perspektywami w skali międzynarodowej"6. Takim punktem widzenia Dikötter niebywale wzburzył wielbicieli Mao, poza ChRL licznych przede wszystkim na uniwersyteckich katedrach. Jeden z nich, indyjski eseista i pisarz Pankaj Mishra, zarzucił mu, że obraźliwie ,pominął stosunek między Mao a ludem chińskim; jak głęboko i szczerze, na przykład, lud ten ufał mu i podziwiał swego przywódcę, zanim

Gao Wenqian, Zhou Enlai: The Last Perfect Revolutionary. A Biography, New York 2007, s. 311. Naturalnie, słowa te nie pochodzą z oficjalnej, „brązowniczej” biografii wydanej w ChRL, ale z pracy, którą Gao - były pracownik Centralnego Biura badawczego KPCh - napisał po wyjeździe na stałe do USA.

6 B. Winterton, Book Review: Republican China Rewritten, „Taipei Times”, 7 XII 2008. 
nie został przezeń zdradzony" jest jasne, jakie to obiektywne dane potwierdzałyby stopień uwielbienia dla $\mathrm{Mao}^{8}$, ten zaś, przynajmniej od 1949 roku, żadnego kontaktu z ,ludem” nie miał), odwołuje się ona właśnie do rzekomych ,złotych lat” reżimu 1949-1957. Autor Tragedii wyzwolenia dostarcza tymczasem dowodu obezwładniającego: tajnych danych samych komunistów, owoców badań z 1956 roku. „Większości tych badań nigdy nie opublikowano - i nie bez przyczyny; wskazywały bowiem, że pod wieloma względami życie było lepsze dwadzieścia lat wcześniej” (s. 311). Nawiasem mówiąc, statystyki w ChRL fałszowano nie od czasu „Wielkiego Skoku” (kiedy świat przestał wreszcie wierzyć groteskowym komunikatom), ale od początku (s. 300). Jeśli zmiany na lepsze zaistniały, to nie dzięki komunizmowi: na przykład w służbie zdrowia „pewien postęp w latach pięćdziesiątych wynikał z nowych odkryć medycznych" (s. 308). Nawet takie zjawisko, jak bezrobocie pod rządami reżimu, często odwołującego się do faraońskich prac niewolniczych, początkowo nie spadło, a wzrosło (s. 65).

Sięgająca często do źródeł lokalnych praca pokazuje - co prawda, wyrywkowo - że niechęć do rządów komunistów przekładała się na nienawiść do samego Mao Zedonga, wbrew stereotypowi o „dobrym cesarzu i jego złych urzędnikach”. $\mathrm{Na}$ zachodnich uniwersytetach nauczano (czasem naucza się do dziś), iż „zwycięstwo komunistów chińskich było kulminacją odwiecznych zmagań chłopskich oraz nowoczesnych walk z zachodnimi i japońskimi próbami kontroli Chin”, „częścią wielkiego cyklu chłopskich ruchów o oswobodzenie narodowe, który ogarnął Azję i Afrykę po II wojnie światowej”. Tymczasem w czasie wojny koreańskiej „,w Linyingu w Henanie rolnicy bezcześcili portrety Mao, wypalając mu oczy, zrywając plakaty, a nawet rzucając się na nie z tasakami” (s. 179). W prowincji Jiangxi partyjni „,inspektorzy natrafili na obszarach wiejskich na gromady dzieci głośno przeklinające Przewodniczącego Mao i rząd” (s. 258). W Nankinie oczekiwano III wojny światowej, krzepiąc się wiadomościami, iż Związek Sowiecki ,poddał się już bezwarunkowo, teraz zbrodniarz wojenny Mao Zedong zostanie aresztowany!” (s. 168).

Dikötter dostarcza sporo dowodów, jak okrutnym, choć zwykle nienagłaśnianym represjom poddano (zwykle tylko domniemanych) przeciwników komunizmu w rzekomo „złotych” pierwszych latach ChRL. Czystki przeprowadzano często bez sądu (nawet w komunistycznym sensie tego słowa); w przeciwieństwie do oskarżonych w widowiskowych ,procesach” właścicieli ziemskich na wsi, urzędnicy państwowi, którzy - na apel samych komunistów - pozostali na stanowiskach po „wyzwoleniu”, nocami po prostu znikali. Skala przedsięwzięcia była tak znaczna, że odpowiedni rozdział (piąty) nosi tytuł Wielki terror. Sprawy te sygnalizowali już inni autorzy, zwłaszcza Francuz Jean-Luc Domenach. Istotnym, własnym wkładem Diköttera jest

P. Mishra, Staying Power: Mao and the Maoist, „New Yorker”, 20 XII 2010, http://www. newyorker.com/magazine/2010/12/20/staying-power-3 [dostęp: 12.11.2016].

8 Istnieją wszelako pewne dane pośrednie. Oto $72 \%$ jeńców chińskich wziętych do niewoli przez siły ONZ w Korei (dokładnie 14 209) wybrało powrót na Tajwan, a nie na rządzony przez komunistów kontynent.

J. Chesneaux, The People's Republic, 1949-1976, New York 1979, s. 14. Autor, wybitny francuski uczony, był wielbicielem chińskiego i wietnamskiego komunizmu. 
natomiast wykazanie, jak szkodliwym nonsensem okazało się wyrzucenie z Chin niemal wszystkich mieszkających tam (czasem od pokoleń) cudzoziemców, których centrum był barwny, kosmopolityczny Szanghaj. Krwawa rozprawa z chińskimi chrześcijanami uderzyła we wspaniale dotąd funkcjonujące szkoły i uniwersytety (na przykład Yenching University założony przez metodystów), a także pozbawiła chiński interior oferowanej przez misje nowoczesnej opieki medycznej. Ponieważ historiografia lewicowa podkreśla zwykle, że cudzoziemcy korzystali w Chinach z raniących dumę gospodarzy przywilejów eksterytorialnych (ich resztki zlikwidowano jednak już w 1943 r.), to warto podkreślić, iż reżim Mao utrzymał je w całej rozciągłości odnośnie do obywateli ZSRR. „Rosyjskich doradców umieszczono w Canton Club - ekskluzywnej posiadłości służącej dawniej Brytyjczykom - nowi lokatorzy mieli do dyspozycji prywatne ogrody, korty tenisowe i boiska piłkarskie. W Tianjinie niektórzy zamieszkali w Jubilee Villas przy London Road, gdzie wejścia pilnowali uzbrojeni strażnicy z pistoletami maszynowymi” (s. 155-156).

$\mathrm{Na}$ tle obecnego faworyzowania przez władze Chin Ludowych biznesmenów, których sekretarz partii Jiang Zemin w 2003 roku uznał za jeden z filarów KPCh, na uwage zasługuje gnębienie tej warstwy przez reżim, zarazem pomysłowe i perfidne. W przeciwieństwie do Lenina, niepozostawiającego nigdy kapitalistom żadnych złudzeń, Mao - głoszący, iż Chiny są na wcześniejszym niż Rosja etapie rozwoju - w latach 1946-1949 uznał „narodową” (czyli wrogą „imperialistom”) burżuazję za partnera robotników i chłopów w walce przeciw Czang Kaj-szekowi. W sytuacji, gdy ludzie biznesu byli przez zwolenników Czanga na potrzeby wojny bezlitośnie eksploatowani, jeśli nie okradani, wezwanie to spotkało się z pewnym odzewem. Rozczarowanie przyszło szybko, ale nie można go było wyrażać głośno. Uderzenia następowały wybiórczo: na przykład wiejskich kupców obwiniono o klęskę głodu, wywołaną w istocie kolektywizacją rolnictwa. Majstersztykiem Mao był jednak pomysł, zrealizowany jesienią 1955 roku, by przedsiębiorcy sami błagali partię, aby natychmiast przeprowadzić nacjonalizację ich zakładów; „wymagano od nich, by publicznie okazywali ogromny entuzjazm" (s. 281). W jakimś sensie przypominało to ostatni - już niezrealizowany - pomysł Stalina, by sowieccy Żydzi sami wystąpili do władz z prośbą o deportowanie ich na Syberię. Dzisiejsze podręczniki w ChRL, zapewniające, iż „KPCh nie uważała chińskiej burżuazji za wrogów i wykorzystywała metodę »samokrytyki«, by uczynić ich wartościowymi obywatelami”, prześlizgują się tylko nad wiadomością, że 20 stycznia 1956 roku w Szanghaju (nb. w gmachu Towarzystwa Przyjaźni Chińsko-Sowieckiej) odbyło się , walne zgromadzenie przedstawicieli kapitalistycznych przedsiębiorstw przemysłowych i handlowych w celu wystąpienia o partnerstwo publiczno-prywatne" ${ }^{\prime 10}$. W rezultacie owego „partnerstwa” „drobnych sklepikarzy spotkała ruina. [...] Państwo zabrało im wszystko, co posiadali, czasami aż po garnki i kołyskę niemowlaka. Rekompensata nie wystarczyła nawet na papierosy. [...] Jeśli próbowali znaleźć pracę gdzie indziej, odkrywali, że zostali sklasyfikowani jako kapitaliści, co oznaczało, że nie przysługują im przywileje,

10 H. Li, Y. Gong, Q. Song, op. cit., s. 93 i 94 (tekst ilustruje fotografia rozpromienionych utratą własności kapitalistów). 
które zwykłym robotnikom dawały choćby pozory bezpieczeństwa. [...] Doszło do fali samobójstw, ale tym razem władze szybko zareagowały" (s. 282). Niektórzy szczęśliwcy, jak były milioner Rong Yiren, który publicznie podarował państwu swe fabryki, potrafili się urządzić w charakterze doradców giętkiego pragmatyka Zhou Enlaia. Większość jednak pożarł komunistyczny moloch.

Godnym uwagi wątkiem jest paranoiczna psychoza, wywołana przez oskarżenia, że Chiny są obiektem ataku z użyciem amerykańskiej broni biologicznej. Prowadziła ona do zjawisk na granicy obłędu; na przykład, aby wykonać narzucone odgórnie normy w zdobyciu martwych szczurów, uciekano się do pokątnej hodowli owych gryzoni. Jest charakterystyczne, że zwykli ludzie nie dawali się przekonać, iż zakażone (jakoby) insekty mogły być zrzucone przez startujące z Korei samoloty, skoro trwała najsroższa od półtora stulecia zima. (,W Korei panują mrozy. Jakim cudem pchły nie zamarzły?" - s. 178). Znacznie bardziej łatwowierni (a chyba raczej: żarliwi) okazali się postępowi zachodni intelektualiści. Smutną kartą jest tu przypomnienie roli Josepha Needhama, autora monumentalnej, trudnej do przecenienia serii Science and Civilisation in China. Badacz o wielkim już światowym autorytecie poparł oskarżenia komunistyczne po wizycie w Mandżurii, przyznając po dekadzie, że jedynym dowodem były rozmowy z „bakteriologami chińskimi” (s. 177 i 379$)^{11}$.

Autor Tragedii wyzwolenia ukazuje, że komunistyczny wandalizm, tak szokujący świat w dobie „rewolucji kulturalnej”, istniał już od pierwszych dni funkcjonowania nowej władzy. Rozbijanie podczas reformy rolnej należących do właścicieli ziemskich antyków można od biedy złożyć na karb lokalnej nadgorliwości. Burzenie grobowców i świątyń (w Jiningu zrównano z ziemią wieżę Taibai, gdzie podobno mieszkał sławny poeta $\mathrm{z}$ czasów dynastii Tang, Li Bai) wymagało jednak działalności planowej i musiało uzyskać aprobatę władz w skali co najmniej powiatu (xian). Szczególny charakter miało niszczenie książek, przy czym nie chodziło o wycofywanie ich z bibliotek, ale o spektakularne, służące celom „wychowawczym” auto da fé. „W Shantou, jednym z portów zgodnie z traktatem otwartych dla zagranicznego handlu w XIX wieku' ${ }^{12}$, w maju 1953 roku ogromne, płonące trzy dni ognisko pochłonęło trzysta tysięcy tomów stanowiących »pozostałości feudalnej przeszłości«" (s. 227). Całopaleniu - podobno „przez przypadek” - ulegały nawet dzieła twórcy Republiki Chińskiej Sun Yatsena (wdowa po nim była wiceprzewodniczącą ChRL). Obok książek unicestwiano na przykład płyty z muzyką jazzową, uznaną za „pornograficzną" (s. 230).

W krótkiej recenzji nie sposób choćby zasygnalizować wielu wątków poruszonych przez autora. Wykazał się on bez wątpienia dużym zmysłem syntezy, na ledwie 339 stronach (nie licząc bibliografii i przypisów) tworząc panoramiczny obraz transformacji, jaka dotknęła najludniejszy kraj świata. Warto jednak wskazać, czego

11 Needham wysławiał Mao i szkalował Czang Kaj-szeka, jednakże (czego Dikötter już nie pisze) jego opus magnum przetłumaczyły na chiński właśnie władze w Tajpej, wypłacając przy tym skrupulatnie honorarium.

12 W oryginale: ,in Shantou, one of the treaty ports opened to foreign trade in the nineteenth century” - nie chodzi więc o jeden konkretny traktat, ale o przynależność do kategorii „portów traktatowych”, które mogły być odwiedzane przez cudzoziemców (w przeciwieństwie do pozostałych portów). 
w książce nie ma (wspomniałem już o zredukowaniu do minimum wewnętrznych dziejów partii). Otóż w zasadzie pominięto kwestie mniejszości narodowych, dla których zwycięstwo KPCh oznaczało trzęsienie ziemi (przed 1949 r. władza centralna często nie sięgała w daleki interior). Z udziału Pekinu w wojnie koreańskiej poznajemy tylko wewnątrzchińskie reperkusje konfliktu. Wojna domowa lat 1945-1949 opisana jest, w znacznej mierze zresztą słusznie, jako mało zrozumiały pojedynek tytanów, obserwowany przez pragnące tylko końca walk, apatyczne społeczeństwo. Ludzie ,po ponad dziesięciu latach strachu i przemocy pragnęli pokoju za wszelką cenę, nawet pod rządami komunistów" (s. 50). Tylko mimochodem dowiemy się, że amerykańska mediacja generała George'a Marshalla w istocie pomogła komunistom pokonać Czang Kaj-szeka i że, wbrew niesłychanie żywotnemu, mówiącemu o miliardach mitowi, „,cała pomoc wojskowa udzielona [narodowym] Chinom po zwycięstwie nad Japonią była warta zaledwie od 225 do 360 milionów dolarów” (s. 42). Mało tego: „Granicę między Mandżurią i Związkiem Radzieckim przekraczały całe pociągi wyładowane sprzętem, natomiast Stany Zjednoczone odmawiały zezwolenia na wysyłkę sprzętu wojskowego do Chin, także tego, za który rząd Czang Kaj-szeka już zapłacił" (s. 39). USA w istocie porzuciły swego walczącego z komunistami sojusznika, a ich polityka odnośnie do chińskiej wojny domowej przyniosła katastrofalną klęskę. Historykowi nie wypada skomentować owej polityki tak, jak zrobił to publicysta Stanisław Cat-Mackiewicz: „Ponieważ klęska ta [polityki USA] została spowodowana przez wycofanie się z pola walki, przez świadome niepodejmowanie obrony, przez ucieczkę, więc zasługuje na przymiotnik »tchórzliwa«"13.

Dikötter przedstawił wizję spójną i przekonującą, napisaną żywym językiem, co nie jest oczywiste u kogoś, dla kogo angielski nie jest, bądź co bądź, mową ojczystą. Spora w tym zapewne zasługa thumaczki Barbary Gadomskiej, ale i samego autora (piszący te słowa przeczytał najpierw The Tragedy of Liberation w oryginale) ${ }^{14}$. Mimo oczywistych konkluzji, omawiane dzieło to nie zaangażowany politycznie pamflet, jak na przykład - skądinąd niezastąpiona informacyjnie - Najnowsza historia polityczna Polski Władysława Poboga-Malinowskiego. Zapewne pojawią się jednak pytania urażonych czytelników, dlaczego autor nie dostrzega w zdobyciu władzy przez KPCh żadnych dobrych stron. Takim pozytywem było na pewno - o czym faktycznie Dikötter nie pisze - zakończenie nieustannych walk wewnętrznych, które wojska pod różnymi flagami prowadziły w Chinach od 1916 roku (od śmierci dyktatora Yuan Shikaia), jeśli nie po prostu od obalenia monarchii w 1911 roku. Zaprowadzenie pokoju jest jednak przywilejem każdego zwycięzcy w wojnie domowej, od Oktawiana Augusta po afgański reżim talibów; rzecz w tym, do czego „pokoju majestat" został potem wykorzystany, a tu pierwszy cesarz Rzymian wypada zdecydowanie lepiej niż fundamentaliści islamscy czy właśnie komuniści chińscy. Tragedia wyzwolenia - powtórzmy to raz jeszcze - opowiada o społeczeństwie chińskim pewnej epoki, a nie o partii komunistycznej. Ta ostatnia była zapewne niezmiernie sprawnym

13 S. Cat-Mackiewicz, Chciatbym przekrzyczeć kurtynę żelazną. „Lwów i Wilno” 1946-1950, Kraków 2016, s. 513 (artykuł, z którego pochodzi cytat, był współczesny wypadkom).

14 Korzystałem z wydania: F. Dikötter, The Tragedy of Liberation: A History of the Chinese Revolution 1945-1957, London-New Delhi-New York-Sydney 2015, ss. 376. 
narzędziem władzy; wielce też prawdopodobne, że - przynajmniej w okresie opisywanym w książce - była ona mniej skorumpowana od poprzednich reżimów władających Państwem Środka. Zważywszy na fakt, iż pieczołowite kolekcjonowanie gustownych przedmiotów starożytnej proweniencji było od zarania dziejów niemal oficjalnym hobby każdego urzędnika chińskiego ${ }^{15}$, ekipa komunistyczna charakteryzowała się początkowo siermiężnym wprost purytanizmem i obskurantyzmem. Biografka przywódcy KPCh Jung Chang napisała o swym (anty)bohaterze, iż „Mao był jedynym milionerem w maoistowskich Chinach" ${ }^{16}$. Jeśli nawet jednak pod tym względem partia wypadała korzystniej od „burżuazyjnych” poprzedników, „historia tego [XX - J.P.] stulecia nauczyła nas, że istnieje coś gorszego niż skorumpowany kapitalizm, a mianowicie brak wszelkiego kapitalizmu"'17.

Błędów stricte merytorycznych jest w pracy niewiele, wyjąwszy notoryczne w zachodniej historiografii nazywanie Związku Sowieckiego „Rosją”. Dikötter powtarza (za Seymourem Toppingiem, nie historykiem, lecz dziennikarzem) zniesławiającą plotkę, jakoby Du Yuminga - dowódcę armii Kuomintangu w rozstrzygającej bitwie z komunistami pod Xuzhou - „złapano, gdy usiłował się przedostać przebrany za zwykłego żołnierza" (s. 49). Naprawdę Du, ciężko chory, nie był zdolny do takiej próby, nawet gdyby jej chciał: nie opuścił swoich podwładnych i poddał się przy swoim stanowisku dowodzenia, gdy jego armia wyczerpała amunicję ${ }^{18}$. Kim Ir Sen w chwili kapitulacji Japonii był kapitanem Armii Czerwonej, nie majorem (s. 159). Nazwisko znakomitego historyka Frederica Wakemana (s. 355) jest zniekształcone, ale to już wina polskiej edycji. Poleganiem na starych schematach i opracowaniach wytłumaczyć można natomiast opinię ze strony 161, że interwencję ChRL w Korei mimowolnie sprowokował głównodowodzący wojsk ONZ generał MacArthur, ponieważ doszedł w październiku 1950 roku do samej granicy chińskiej na rzece Yalu, ,ignorując najbardziej zasadnicze obawy Chińskiej Republiki Ludowej o swoje bezpieczeństwo". Wybiórcza kwerenda w archiwach pekińskich, którą przeprowadził chińsko-amerykański historyk Chen Jian, wykazała bowiem, że ,jest jasne, iż Mao Zedong i kierownictwo KPCh postanowili wysłać wojska chińskie do Korei już w końcu sierpnia i na początku września" ${ }^{19}$. Było to nie tylko przed osiągnięciem Yalu, ale nawet przed przełamaniem frontu przez MacArthura, a celem była nie obrona Chin, lecz zdobycie całej Korei dla komunizmu. Prawdą jest natomiast, że w owych miesiącach właśnie Mao „dążył do wojny, gdy jego towarzysze się wahali”

15 http://www.mnw.art.pl/wystawy/zycie-wsrod-piekna-swiat-chinskiego-uczonego-sztuka-z-chinskiegomuzeum-narodowego,177.htm (wystawa, zorganizowana przez Muzeum Narodowe w Warszawie oraz Chińskie Muzeum Narodowe w Pekinie, trwała w momencie pisania tej recenzji, czyli w listopadzie 2016 r.).

16 J. Chang, J. Halliday, Mao, tłum. P. Amsterdamski, Warszawa 2007, s. 334 (mąż Jung Chang, Jon Halliday, uznany został za współautora książki głównie za wkład w zbieranie materiałów oraz szlifowanie stylu urodzonej w ChRL małżonki).

17 D.G. Gillin, Falsifying China's History: The Case of Sterling Seagrave's The Soong Dynasty, Stanford, CA 1986, s. 24.

18 A.O. Westad, Decisive Encounters: The Chinese Civil War, 1945-1950, Stanford, CA 2003, s. 209.

19 Chen Jian, China's Road to the Korean War: The Making of the Sino-American Confrontation, New York 1995, s. 154. 
(s. 167). A przecież mogło być jeszcze gorzej. Niewiele bowiem brakowało - autor Tragedii wyzwolenia tego nie pisze - by owo niepoczytalne pragnienie rozciągnięcia budownictwa komunistycznego na cały Półwysep Koreański (jakby mało było do zrobienia w granicach Chin, od 1911 r. trawionych wojną domową) nie ściągnęło na Państwo Środka niszczących uderzeń nuklearnych.

Summa summarum, praca Diköttera jest fascynującą, acz jednocześnie ogromnie przygnębiającą lekturą. Smutek, jaki wywołuje jej czytanie, ma wszakże jeszcze jedną przyczynę i chciałbym ją w tej recenzji możliwie silnie zaakcentować. Otóż fakty, z którymi zaznajamia nas autor, tak naprawdę nie są ani zaskakujące, ani nowe. Abstrahując od pisarskiej sprawności holenderskiego badacza, jego główny wkład polegał na dostarczeniu archiwalnej podbudowy tezom znanym od samego powstania reżimu. Głosili je ludzie zasiadający we władzach Republiki Chińskiej na Tajwanie oraz uciekinierzy z ChRL - cudzoziemcy, ale przeważnie jednak Chińczycy. Wiele prac często cytowanych w Tragedii wyzwolenia - na przykład wspomnienia Roberta Loha, Petera Luma, biskupa Quentina K.Y. Huanga - wydano w latach 50. i 60. XX wieku. Opowieści podobne do cytowanych w Tragedii wyzwolenia przekazywali masowo uciekinierzy docierający do rządzonego wtedy przez Brytyjczyków Hongkongu (jednego z niewielu miejsc, dokąd czasami udawało się uciec). Potomek jednego z nich skomentował książkę Diköttera na stronie internetowej księgarni Amazon: „Pamiętam, że jak byłem dzieckiem, mama strofowała mnie, bym zjadał wszystko, co mi podają, i pilnie się uczył. »Jeśli przyjdą komuniści, nie będą ci mogli odebrać tego, co zjadłeś, i wiedzy, jaką zdobyłeś. Wszystko inne mogą ci odebrać«. Frapowało mnie, kim są komuniści i co rozumie przez owe słowa. Ciągle mam przed oczami zdanie po chińsku wypisane na zboczu drogi wiodącej z Kowloon do Shatinu ${ }^{20}$ : »Gdy nadejdą komuniści, ludzie umrą, a rodziny zostaną rozdzielone«"21.

Niestety, wspomnianych prac nie dostrzegała zachodnia historiografia, pozostały literaturą niszową. Czasem przyczyną była mała dostępność, wynikająca z egzotycznego miejsca publikacji (na przykład cenną relację Mariano Ezpelety wydano w 1972 r. w Quezon City na Filipinach). Główny powód był jednak inny - ponieważ rzeczeni autorzy byli prześladowani przez komunistów, ich prace uznano za stronnicze (ang. biased) i dlatego niewarte uwagi. Innymi słowy, potraktowano je tak samo, jak relacje „,białych” emigrantów rosyjskich, a potem i nierosyjskich uciekinierów z ZSRR. Nastawienie takie, kompromitujące dla badacza (wadą świadka miał być fakt, że był świadkiem naocznym), zrodziło dokładnie te same skutki, a mianowicie odkrywanie po latach „szokujących i sensacyjnych” faktów, od dawna znanych i odkrytych.

Ważną grupę wśród wspomnianych wyżej źródeł stanowią materiały proweniencji misyjnej. Nie z powodu liczebności chińskich chrześcijan - grupa ta, acz nadreprezentowana wśród elit intelektualnych kraju, była tradycyjnie niewielka - ale z powodu obecności misji we wszystkich właściwie regionach Państwa Środka,

${ }^{20}$ Chodzi o szosę z półwyspu Kowloon (stanowiącego zaplecze wyspy Hongkong) do miasteczka Shatin na granicy ChRL.

${ }^{21}$ Cyt. za: https://www.amazon.com/Tragedy-Liberation-History-Revolution-1945-1957/dp/1620403498/ ref-pd_sim_14_1?_encoding=UTF8\&psc=1\&refRID=76CB35TZGZB4QPXNHN7X [dostęp: 9.11.2016]. 
a także faktu, że misjonarze - jedyni cudzoziemcy żyjący niejako wewnątrz społeczeństwa chińskiego - mieli mimo wszystko szanse na opuszczenie Chin. Będąc ośrodkami nauczania, szczególnie ważnego w wypadku dziewcząt, upośledzonych w kulturze chińskiej pod względem dostępu do edukacji, misje oferowały też pomoc medyczną, zwykle najbardziej profesjonalną, jaką wieś chińska mogła otrzymać ze źródeł pozarządowych. Po „wyzwoleniu” zostały zamknięte, podobnie zresztą jak większość buddyjskich i taoistycznych ośrodków dobroczynnych. Frank Dikötter do źródeł misyjnych sięga tylko incydentalnie, przy czym są to wyłącznie źródła drukowane. Tymczasem, jak ostatnio przypomniała znakomita kanadyjska badaczka Diana Lary, sama tylko jezuicka prowincja Xuzhou w latach 1918-1954 wyprodukowała kilometry akt dostępnych obecnie w Montrealu. Dziś nie interesuje się nimi niemal nikt. „Do lat osiemdziesiątych, gdy owe materiały zostały opublikowane, pobożny świat, który je wytworzył, uległ Cichej Rewolucji [Révolution tranquille - fala sekularyzacji i dechrystianizacji w Quebeku pod rządami Jeana Lesage'a i Roberta Bourassy] i zostały zapomniane w laickim, nacjonalistycznym świecie nowego Quebeku"22.

Historycy mają skłonność do przepraszania nie większą od innych uczonych, lecz wyrządzone przez nich szkody - swoiste zmienianie przeszłości (w której to umiejętności, jak głosi złośliwe porzekadło, dziejopisowie przewyższają samego Stwórcę) - są pod pewnymi względami gorsze od innych. Sympatycy Mao na uniwersyteckich katedrach historycznych i politologicznych (ich nieformalnym „papieżem” był harwardzki badacz John King Fairbank, znany z opinii, że maoizm jest „najlepszą rzeczą, jaka wydarzyła się w Chinach w ciągu wieków”23) wyrządzili olbrzymie szkody, często nie do naprawienia. Nie tylko bałamucili opinię publiczną swoich krajów, ale także wpływali na politykę rządów. Mimo niewątpliwych naukowych zasług (Fairbank był inicjatorem i współredaktorem monumentalnej The Cambridge History of China) ciemna strona ich działalności nie powinna być zapomniana, choćby apologeci robili z nich „ofiary maccartyzmu”"24. Książki takie jak Tragedia wyzwolenia nie tylko demaskują ich jako kłamców, ale również przywracają odpowiednią rangę zniesławianemu przez nich dorobkowi ośrodków tajwańskich. Opracowania badaczy

22 D. Lary, A Ravaged Place: The Devastation of the Xuzhou Region [w:] Scars of War: The Impact of Warfare on Modern China, eds. D. Lary, S. MacKinnon, Vancouver-Toronto 2001, s. 115.

${ }_{23}$ J.K. Fairbank, The New China and American Connection, „Foreign Affairs” 1971, vol. LI, nr 1, s. 36. Siłę rażenia takich opinii wyznaczała nie tylko ranga autora (już wtedy bardzo znanego), ale i czasopisma, jako bodaj najważniejszego periodyku politologicznego w świecie zachodnim.

24 Zob. H.D.L. Gordon, S. Chang, John King Fairbank and His Critics in Republic of China (Review Article), „,The Journal of Asian Studies”, November 1970, vol. XX, no. 1, s. 137-149. Ponieważ Fairbank i jego ideowi sprzymierzeńcy, rzeczywiście obwiniani w USA po 1949 r. za „utratę Chin” na rzecz komunistów, konsekwentnie wzywali do porozumienia z Mao, to na początku lat 70 . XX w., gdy to porozumienie istotnie nastąpiło (na zupełnie nieoczekiwanej, antysowieckiej płaszczyźnie), uznano ich za politycznych wizjonerów. Było to, najoględniej mówiąc, nieporozumienie: w latach 70. USA (przy pomocy komunistycznych Chin) zwalczały w Azji Wschodniej zagrożenie, które w ogóle by nie powstało, gdyby nie polityka Waszyngtonu wobec innych Chin, niekomunistycznych, w latach 1946-1949. 
nawet jawnie zaangażowanych politycznie w sprawę Czang Kaj-szeka były bowiem „często przesadne, ale rzadko fałszywe" ${ }^{25}$.

Ostatecznie podbój Chin przez komunistów jawi się po 70 latach jako zjawisko przypominające w niejednym XIII-wieczny podbój mongolski, a mianowicie „przekleństwo w pełnym tego słowa znaczeniu”26. Jeśli towarzyszy Czyngis-chana mieszkańcy Państwa Środka postrzegali jako „prymitywnych dzikusów zdolnych jedynie do niszczenia i do zdeprawowanych wybryków, opojów, zabobonnych oraz brutalnych"27, w wypadku zaś towarzyszy Mao oficjalne opracowania kładą nacisk na ich wszechstronne osiągnięcia (co prawda głównie po śmierci wodza i ukróceniu najjaskrawszych „błędów i wypaczeń”), to warto zauważyć, iż po mongolskiej dynastii Yuan pozostały arcydzieła w postaci powieści, dramatów oraz architektury, a mocarstwowa pozycja Chin była wówczas bardziej ugruntowana niż dziśs ${ }^{28}$. Nie kwestionując osiągnięć - których co prawda znaczna część najbardziej zainteresowanych nie dożyła - stwierdzić można, słowami generała Władysława Andersa, że są to „bardzo wielkie osiągnięcia, ale kosztem zbyt wielkich ofiar w ludziach”"29.

I ostatnia uwaga: szkoda, że edycja polska pozbawiona jest ciekawych fotografii, które znalazły się w wydaniu oryginalnym.

Wydawnictwu Czarne należy się wdzięczność. Frank Dikötter wydał właśnie pracę o ,rewolucji kulturalnej”, mającą (po wydanym już Wielkim Głodzie) dopełnić jego tryptyk na temat maoizmu ${ }^{30}$. Piszący te słowa, od lat zafascynowany dziejami Republiki Chińskiej, chętnie widziałby polskie wydanie The Age of Openess. Niemniej najważniejszą z dotychczasowych prac Diköttera właśnie w Polsce opublikowano.

\section{BIBLIOGRAFIA}

\section{Pamiętniki}

Anders W., Bez ostatniego rozdziału. Wspomnienia z lat 1939-1946, Londyn 1950.

25 J.-L. Domenach, Chine, l'archipel oublie, Paris 1992, s. 558.

26 W. Rodziński, Historia Chin, s. 233. Autor, wspomniany już, zdecydowany sympatyk ChRL, użył tego sformułowania właśnie wobec najazdu Mongołów.

27 E.O. Reischauer, J.K. Fairbank, East Asia: The Great Tradition, London 1958, s. 275.

28 Można zauważyć, że po dekadach opisywania w podręcznikach ChRL Mongołów jako niemal dwunogich bestii, współczesna historiografia Chin Ludowych zaczyna kłaść nacisk na chiński charakter oraz mocarstwowy blask dynastii Yuan, prezentując jednocześnie Czyngis-chana jako jednego z rodzimych cesarzy i bohaterów narodowych (chińskich tytułów monarszych rzeczywiście - ale retrospektywnie - używali wobec swego antenata władcy z dynastii Yuan). Zabiegi te budzą oburzenie w niepodległej Mongolii, powodując oskarżenia o imperializm i próbę kradzieży cudzej historii.

29 W. Anders, Bez ostatniego rozdziału. Wspomnienia z lat 1939-1946, Londyn 1950, s. 161.

30 Książka ta (The Cultural Revolution: A People's Story, 1962-1976) ukazała się w maju 2016 r. nakładem Bloomsbury Press. 


\section{Monografie, rozprawy, artykuły}

Cat-Mackiewicz S., Chciałbym przekrzyczeć kurtynę żelazną. „Lwów i Wilno” 19461950, Kraków 2016.

Chang J., Halliday J., Mao, tłum. P. Amsterdamski, Warszawa 2007.

Chen Jian, China's Road to the Korean War: The Making of the Sino-American Confrontation, New York 1995.

Chesneaux J., The People's Republic, 1949-1976, New York 1979.

China: Big Bad Wolf, „The Economist”, 31 VIII 2006, http://www.economist.com/ node/7854042 [dostęp: 12.11.2016].

Davin D., Mao Zedong, thum. E. Spirydowicz, Warszawa 2000.

Dikötter F., The Age of Openess: China Before Mao, Hong Kong 2008.

Dikötter F., The Cultural Revolution: A People's Story, 1962-1976, London-New DelhiNew York-Sydney 2016.

Dikötter F., The Tragedy of Liberation: A History of the Chinese Revolution 1945-1957, London-New Delhi-New York-Sydney 2015 (wyd. polskie: Tragedia wyzwolenia. Historia rewolucji chińskiej 1945-1957, tłum. B. Gadomska, Wołowiec 2016).

Domenach J.-L., Chine, l'archipel oublie, Paris 1992.

Fairbank J.K., The New China and American Connection, „Foreign Affairs” 1971, vol. LI, nr 1, s. 31-43.

Gillin D.G., Falsifying China's History: The Case of Sterling Seagrave's The Soong Dynasty, Stanford, CA 1986.

Gordon H.D.L., Chang S., John King Fairbank and His Critics in Republic of China (Review Article), „The Journal of Asian Studies”, November 1970, vol. XX, no. 1, s. 137149.

Lary D., A Ravaged Place: The Devastation of the Xuzhou Region [w:] Scars of War: The Impact of Warfare on Modern China, eds. D. Lary, S. MacKinnon, Vancouver-Toronto 2001, s. 98-116.

Li H., Gong Y., Song Q., Chińska droga, tłum. K. Kukowska, Toruń 2014.

Mishra P., Staying Power: Mao and the Maoist, „New Yorker”, 20 XII 2010, http://www. newyorker.com/magazine/2010/12/20/staying-power-3 [dostęp: 12. 11. 2016].

Polit J. [recenzja z: H. Li, Y. Gong, Q. Song, Chińska droga, Toruń 2014], „Studia Historyczne" 2015, nr 1, s. 136-138.

Rodziński W., Historia Chin, Wrocław 1992.

Rodziński W., The People's Republic of China: Reflections on Chinese Political History since 1949, London 1988.

Reischauer E.O., Fairbank J.K., East Asia. The Great Tradition, London 1958.

Scars of War: The Impact of Warfare on Modern China, eds. D. Lary, S. MacKinnon, Vancouver-Toronto 2001.

Gao Wenqian, Zhou Enlai: The Last Perfect Revolutionary. A Biography, New York 2007. Westad A.O., Decisive Encounters: The Chinese Civil War, 1945-1950, Stanford, CA 2003. Winterton B., Book Review: Republican China Rewritten, „Taipei Times”, 7 XII 2008. 